\title{
THE ECONOMIC VALUE OF GREEN OPEN SPACE AREA IN MEDAN BASED ON TYPE OF LAND USE
}

\author{
MONA FHITRI SRENA ${ }^{1 *)}$, RACHMAD HERMAWAN ${ }^{2)}$ AND BAHRUNI $^{3)}$ \\ 1) Management of Ecotourism and Environmental Services, Department of Forest Conservation Resources and \\ Ecotourism, Faculty of Forestry and Environment Institut Pertanian Bogor, Bogor, 16880, Indonesia \\ 2) Department of Forest Conservation Resources and Ecotourism, Faculty of Forestry and Environment Institut \\ Pertanian Bogor, Bogor, 16680, Indonesia \\ 3) Departement of Forest Management, Faculty of Forestry and Environment Institut Pertanian Bogor, Bogor, 16680, \\ Indonesia \\ *Email: monaputrisrena@apps.ipb.ac.id
}

Accepted August 05, 2021 / Approved September 01, 2021

\begin{abstract}
Medan City which is the capital of North Sumatra Province has many environmental problems, so it requires the existence of green open space could ameliorate microclimate. Air temperature and humidity as part of the microclimate element affect the level of comfort that will ultimately affect quality the of society. It is necessary to quantitatively calculate the economic value of the urban forests so that their existence is considered a need for the city. This study aims to estimate the economic value of green open space based on biotic, physical, and social factors in residential areas, business and office areas, and industrial areas in Medan City. The research was conducted in Cadika, Beringin, and Maharani green open spaces. The research data was collected during December 2020-February 2021. The data analysis method is using multiple linear regression analysis. The result showed quantitatively through the green open space temperature humidity index value it falls into the uncomfortable category (THI>26) but qualitatively by perception visitors and communities that urban forests are comfortable. Total WTPs from green open space visitors with a visiting period which is valued at Rp. 29,268,000/year. Based on the hedonic price analysis, the closer 1 meter to the green space will increase the price of different properties in each green open space.
\end{abstract}

Key words: economic value, green open space, Medan City, willingness to pay

\section{INTRODUCTION}

The city of Medan, the capital of North Sumatra Province, is a city with fairly rapid development. In 2018, the population of Medan City reached 2,264,145 people. Compared to the population in 2017, there was a population increase of 16,720 people $(0.74 \%)$. With an area of $265.10 \mathrm{~km}^{2}$, a population density of 8,541 people $/ \mathrm{km}^{2}$ (BPS, 2019). This population growth has resulted in increased community activities which in turn resulted in the increasing need for land use in the city of Medan, such as the need for residential areas as residences, business and office areas, and industrial areas. These areas are developing and land use in meeting the needs of the people in the city of Medan. The use of the land then results in environmental problems and a decrease in environmental quality.

The city of Medan as a residential area requires good environmental quality so that it makes it comfortable for its residents. People who live in urban areas with diverse activities also need space as a means of recreation. One of the efforts to realize comfort and fulfill recreational needs is to build and manage Green Open Space properly. However, the existence of green open space has not been realized by various parties. One of the reasons is that people's knowledge is still limited and the benefits of green open space are intangible which makes the area seem unimportant. Suryandari (2015) in her research stated that based on the area of Medan City, which is 26,510 ha and the need for green open space according to Law Number 26 of 2007 is 30\% of 26,510 ha, the need for green open space in Medan is around 7,953 ha consisting of 5,302 ha of public green open space and 2,651 ha of private green open space. However, based on data from the Sanitation and Parks Service of Medan, the area of the green open space in Medan City currently does not reach $10 \%$. Effendy et al. (2006) stated that a $10-50 \%$ decrease in green open space will increase the air temperature by $0.2-1.8^{\circ} \mathrm{C}$, whereas an increase of $10-50 \%$ green open space reduces the air temperature by $0.1-0.5^{\circ} \mathrm{C}$. This research was conducted to build public awareness of the importance of green open space and to know the value of green open space including quantitatively calculating the economic value of green open space based on biotic, physical, and social factors in residential areas, business and office areas, and industrial areas.

\section{RESEARCH METHOD}

The research was carried out from December 2020 to February 2021. The research locations were in the Cadika green open space located in Medan Johor District which represented green open space in the residential 
area, the Beringin green open space located in Medan Baru District which represented green open space in the business and office area, and RTH Maharani which is located in the Medan Industrial Estate (KIM) in the District of Medan Deli, Medan City, North Sumatra Province.

The tools used in this study include a map of the spread of green open space, a portable digital thermometer, a digital camera, a questionnaire, stationery, and Google Earth software. The objects studied were urban forest green open space, city park visitors, and the people who live around the research location.

The types of data used in this study include primary and secondary data. Primary data was obtained by direct observation and measurement at the research location consisting of temperature and humidity data, as well as distributing questionnaires to respondents. Secondary data based on data that support this research were obtained from literature studies and information from related agencies.

The perception data was carried out on two types of visiting days, namely on weekdays between Monday to Friday (low visits) and on weekends or holidays, national holidays, school holidays, and work holidays. Respondents were determined through a non-probability sampling approach, namely the accidental sampling method, namely the respondents who were sampled were at the research location and were willing to be interviewed. The number of respondents taken is 30 respondents randomly on weekdays and weekend at each research location. Respondents from the visitors were selected based on the distance between the respondent's residence and green open space as the research location. In this case, selected respondents who live in one district with green open space research location with respondents from each district, namely 30 respondents. Perception data were obtained by using a questionnaire method with closed questions to the respondents. The scale used is a Likert scale from a score range of 1-5. Perceptions of the benefits of green open space and air comfort are presented in tabulated form and analyzed descriptively qualitatively.

Measurement of air temperature and humidity is carried out inside and outside the green open space area. Measurements of air temperature and humidity in green open space were carried out at 12 randomly selected points. Measurement of air temperature and humidity outside the green open space is carried out at measurement points around the green open space which is carried out by dividing the distance into four rings, 25 m (Radius 1/ R1), 50 m (Radius 2/ R2), 100 m (Radius 3/ $\mathrm{R} 3$ ), and $500 \mathrm{~m}$ (Radius 4/R4) from green open space area. The measurement data of air temperature and humidity were taken three times in repetition at each predetermined point, namely in the morning $(8-10$ $\mathrm{AM})$, noon (12 - $2 \mathrm{PM})$, and afternoon (3 - 5 PM). Measurements were made by positioning a portable digital thermometer as high as 1.5 meters from the ground. The measurement at the selected data collection point is a shaded location and is in an open space.

The ability of green open space in microclimate amelioration is seen based on the comparison distribution of the trend of temperature and humidity inside the green open space and outside the green open space with a certain distance. The trend of temperature and humidity is then analyzed descriptively. This is done to determine the effect of city parks in improving the microclimate. Based on the actual microclimate data (temperature and humidity) obtained an air comfort level can be seen based on the air comfort index by McGregor and Nieuwolt (1998) using the Temperature Humidity Index (THI) formula. This index is a value that shows the comfort level of an area quantitatively.

$$
\begin{array}{ll}
\text { THI }=0.8 \mathrm{~T} & +\frac{R H x T}{500} \\
\text { Notes: } & \text { : Temperature Humidity Index } \\
\text { THI } & : \text { Air Temperature }\left({ }^{\circ} \mathrm{C}\right) \\
\mathrm{T} & : \text { Humidity }(\%)
\end{array}
$$

The Temperature humidity index value is influenced by air temperature $\left({ }^{\circ} \mathrm{C}\right)$ and humidity $(\%)$. McGregor and Nieuwolt (1998) stated that the comfort index was generally divided into 3 conditions, namely comfortable (THI: 21-23), moderate/ some people stated comfortable (THI: 24-25), and uncomfortable (THI: $\geq$ 26).

Furthermore, assessments involving environmental services and natural resources that do not have market prices require an approach in measuring the characteristics of these natural resources. Estimation of the economic value of green open space is obtained through direct willingness to pay (WTP) using the contingent valuation method (CVM). CVM is a survey based method to collect the preferences of the person to express directly their willingness to pay (Fauzi, 2010). The determination of the amount of the WTP value offer directly uses open-ended questions. Estimation of the economic value of green space is also carried out using the building price approach using the hedonic price method (HP). The WTP and HP function model were using a multiple regression model

\section{RESULT AND DISCUSSION}

\section{Temperature humidity index (THI) of Green Open Space and Around}

The microclimate is a climatic condition in a very limited space, but this climate component is also important for human, plant, and animal life, because air conditions on a micro-scale directly affect living things (Lakitan, 2002). Local climatic factors such as air temperature and humidity can influence a person's comfort. The air temperature in the city park and its surroundings varies based on time, vegetation structure, 
and distance from the city park. Based on the data obtained during the measurement, the air temperature is affected by time.

The average air temperature is also influenced by the distance the measurement is taken. The relationship between the effect of distance to green open space on temperature and humidity, each green open space is different. The further away from the green open space, there is an increase in air temperature and a decrease in the humidity in the morning, afternoon, and evening. The results of Purwandani (2018) research show that the distribution of green open space is radially spreading on the edge of Banjarmasin City, as well as the pattern of air temperature. The lowest air temperature in green open spaces and the highest in green open spaces. The comfort of an area is strongly influenced by the local microclimate because climate elements will be directly involved in the activities and human metabolism in it (Lakitan, 2002). Air comfort in the three green open spaces ranged from 25-31 (Table 1), which means moderate to uncomfortable according to the index stated by McGreger and Nieuwolt (1998).

Based on the results of the study in Table 1 illustrates that the Beringin green open space and Maharani green open space in the business and office areas, as well as industrial areas, are in the uncomfortable category, both in the morning, afternoon, and evening. However, in the Cadika green open space in the morning, it is in the moderate category or some people say it is comfortable, but in the afternoon and evening, it is in the uncomfortable category. Based on this, by taking into account the higher temperature outside the green open space and lower humidity, the comfort value of the air outside the green open space will be much higher than the THI value, meaning that it is more uncomfortable than inside the green open space, both in the morning, afternoon and evening. day. This is related to the temperature and humidity of the air which can have an impact on whether or not a place is comfortable, the higher the temperature and humidity values, the higher the THI value. Based on the Tampubolon thesis research (2017), people are now starting to feel uncomfortable with the urban environment. This is due to the increasing and diverse urban activities as well as the increasing number of open spaces being converted into built-up lands, such as increasingly dense population settlements and rapidly growing shopping, office, and industrial centers.

Microclimate data on the three green open spaces shows air temperatures ranging from $26-33^{\circ} \mathrm{C}$. Thus, the air temperature range is classified as cool $(25.1-27.1$ $\left.{ }^{\circ} \mathrm{C}\right)$ in the morning to very hot $\left(>31^{\circ} \mathrm{C}\right)$ in the afternoon based on the modified temperature index of climatic conditions from Kusmir (2005) in Setyowati (2010).

\section{Public Perception of the Air Comfort of Green Open Space}

Perception is one of the important psychological aspects of humans. According to Sugihartono et al. (2007), this perception is a psychological aspect of humans in responding to the presence of various aspects and symptoms around them. Public perception of the environment, which in this study is the perception of air comfort becomes important to know as subjective air comfort information from respondents. Public perception of air comfort is presented in Figure 1.

Tabel 1. Value of THI (Tempertaure Humidity Index) aroud Green Open Space.

\begin{tabular}{|c|c|c|c|c|c|c|c|}
\hline \multirow{2}{*}{ Radius } & \multirow{2}{*}{ Green open space } & \multicolumn{2}{|r|}{$8-10 \mathrm{AM}$} & \multicolumn{2}{|c|}{$12-2 \mathrm{PM}$} & \multicolumn{2}{|r|}{$3-5$ PM } \\
\hline & & THI & Note & THI & Note & THI & Note \\
\hline \multirow{3}{*}{ RTH } & Beringin & 25 & moderate & 30 & uncomfortable & 27 & uncomfortable \\
\hline & Cadika & 26 & uncomfortable & 30 & uncomfortable & 28 & uncomfortable \\
\hline & Maharani & 26 & uncomfortable & 31 & uncomfortable & 28 & uncomfortable \\
\hline \multirow{3}{*}{$\mathrm{R} 1$} & Beringin & 25 & moderate & 30 & uncomfortable & 27 & uncomfortable \\
\hline & Cadika & 26 & uncomfortable & 30 & uncomfortable & 28 & uncomfortable \\
\hline & Maharani & 26 & uncomfortable & 31 & uncomfortable & 28 & uncomfortable \\
\hline \multirow{3}{*}{$\mathrm{R} 2$} & Beringin & 25 & moderate & 30 & uncomfortable & 28 & uncomfortable \\
\hline & Cadika & 26 & uncomfortable & 30 & uncomfortable & 28 & uncomfortable \\
\hline & Maharani & 26 & uncomfortable & 32 & uncomfortable & 28 & uncomfortable \\
\hline \multirow{3}{*}{ R3 } & Beringin & 25 & moderate & 30 & uncomfortable & 28 & uncomfortable \\
\hline & Cadika & 26 & uncomfortable & 30 & uncomfortable & 28 & uncomfortable \\
\hline & Maharani & 26 & uncomfortable & 32 & uncomfortable & 28 & uncomfortable \\
\hline \multirow{3}{*}{ R4 } & Beringin & 26 & uncomfortable & 30 & uncomfortable & 28 & uncomfortable \\
\hline & Cadika & 26 & uncomfortable & 30 & uncomfortable & 28 & uncomfortable \\
\hline & Maharani & 27 & uncomfortable & 32 & uncomfortable & 28 & uncomfortable \\
\hline
\end{tabular}


Public perception of the comfort of the air at each location shows various results. Overall, the public perceives the comfort of the air in green open space as being on an uncomfortable scale. The community's perception is influenced by the distance from the green open space. The farther the distance from the green open space, the visitor's perception of the comfort of the air is getting lower or more uncomfortable.

This is in line with the results of air comfort measurements carried out on the three green open spaces which show the THI value in the morning, afternoon, and evening, which is 26 which is in the uncomfortable category. This shows that subjectively and qualitatively related to the air comfort that is felt by the people is on an uncomfortable scale, and also objectively through the calculation of the THI value, it is also in the uncomfortable category. The habits and environment of each individual with different conditions are things that affect the perception of comfort. According to Sangkertadi (2013) which states that apart from microclimate factors, the outdoor thermal comfort environment is also shaped by human factors, such as activity, body size, and the type of clothing worn.

Public perception of air comfort when viewed based on the distance from green open space to their residence has increased. The further the distance from the green open space to their residence, the higher the air temperature obtained during the measurement. This is also in line with the results of research by Ramdhoni et al. (2016) which states that during 2001-2014 the trees in Jakarta decreased by $5.1 \%$ while the area under construction increased by $13 \%$, this caused the surface temperature to increase by about $2-4^{\circ} \mathrm{C}$, while the air temperature increased by about $2-3^{\circ} \mathrm{C}$.

\section{The Economic Value of Green Open Space \\ a. Willingness to pay}

Economic value is defined as the maximum amount that a person is willing to spend in the form of goods and services to obtain other goods and services. Valuation of economic value is an effort to provide a quantitative value for goods and services produced by natural resources and the environment, both based on market value and non-market value. Assessment of environmental services and natural resources that do not have market prices requires an approach in measuring their characteristics. These characteristics were measured using the Stated Preference Method (SP). There are two approaches used in the SP method, namely the Contingent Valuation Method (CVM) and Choice Experiment (CE) (Fauzi, 2014). Contingent Valuation Method (CVM) is used to measure the value of air comfort obtained from the community's Willingness to Pay (WTP) for the construction and development of green open space as an effort to improve environmental quality through increasing air comfort in the respondent's residential area. In addition to using Willingness to pay, the value of the existence of green open space is also assessed using hedonic price analysis. the distance of the house to the nearest green open space which is an attribute that is thought to affect the price of existing land or property.

Measurement with the concept of WTP will translate the ecological value of the ecosystem into economic. The value of willingness to pay green open space visitors is very diverse. The average WTP at each time the contribution of visitors is presented in Table 2.

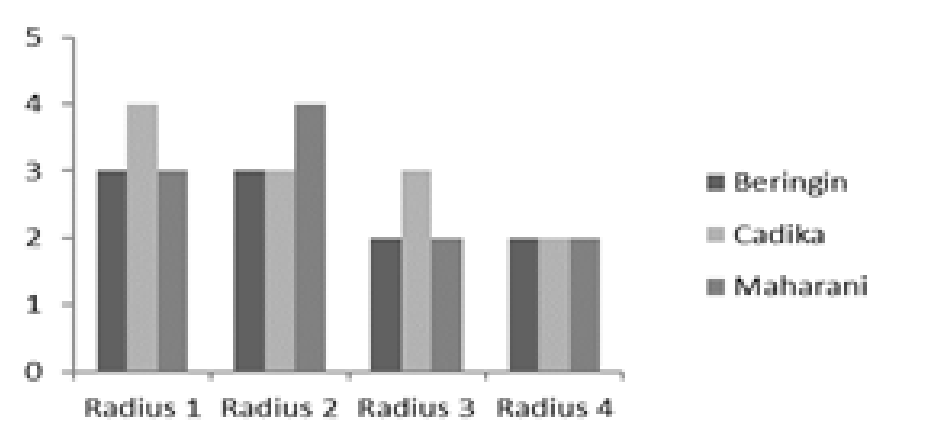

Figure 1. Public perception of air comfortability

Notes : 1 (very uncomfortable), 2 (uncomfortable), 3 (moderate), 4 (comfortable), 5 (very comfortable), Radius 1 (25 m), Radius 2 (50 m), Radius 3 (100 m), Radius 4 (500 m)

Table 2. Total WTP of visitors in one year

\begin{tabular}{|c|c|c|}
\hline RTH & Average of WTP per visit period (Rp) & Total WTP per visit per year (Rp/year) \\
\hline Beringin $^{1}$ & Rp. 5,800 & Rp. $2,088,000^{2}$ \\
\hline Cadika $^{1}$ & Rp. 10,833 & Rp. $3,900,000^{2}$ \\
\hline Maharani $^{1}$ & Rp. 6,467 & Rp. $23,280,000^{3}$ \\
\hline Total & & Rp. $29,268,000$ \\
\hline
\end{tabular}

Notes: ${ }^{1} 30$ respondents, ${ }^{2}$ frequency of visits 1 time a month, ${ }^{3}$ frequency of visits 10 times a month 
The average willingness to contribute visitors during the visit contribution period has the highest value is the Cadika RTH which is located in a residential area. This is also in line with the condition of the Cadika green open space, the vegetation in the green open space has a higher density than the other two green open spaces, a denser canopy cover seen from the higher LAI value, lower noise value, and more diverse facilities and attractions. contained in the green open space is also one of the factors for the high contribution of visitors to Cadika's green open space. Judging from its characteristics, respondents who visited Cadika's green open space were dominated by visitors of productive age (students/students) who were in the range of 20-29 years. Various facilities such as sports facilities, jogging track, roller skate arena, soccer field, canoe play spots, as well as other supporting facilities which can then be enjoyed by visitors of the productive age. Based on the estimated total WTP value, the economic value of green open space with the approach of the total WTP value in the period of visitor contributions per visit in a year is $R p$. 29,268,000/year. The highest total WTP per visit per year is found in Maharani green open space which is located in an industrial area. This is related to the higher frequency of visitors to the Maharani green open space compared to other green open spaces, namely the average visitor comes to visit the green open space 10 times a month. Based on Rahmawati's research (2018), a higher frequency of respondent visits to a city park can lead to a sense of belonging and a sense of desire to take part in developing a city park that is larger than others. This value is also the minimum value that is expected to be obtained, because the real number of visits to each green open space is not known. It is assumed that the total WTP of the actual visitors will be much greater than the value obtained in this study.

Based on this, it can be an illustration of the potential contribution of the community per year that can be used as a source of funding for the development and construction of green open space in the city of Medan. The factors that affect the value of WTP were analyzed using the WTP function (Table 3).

Based on the linear regression model in Table 3, the influencing variables are gender, age, marital status, education, and income. The model generated from this research is good. This is related to the R-square value of each location which is more than 0.15. Garrod and Willis (1999) stated that in research with CVM for environmental goods, the R-square obtained was at least 0.15. The coefficient of determination or R-square essentially measures how far the model's ability to explain variations in the dependent variable (Ghozali, 2009). The value of the coefficient of determination or R-square is zero to one. Based on Ghozali (2009), a small coefficient of determination means that the variation in the dependent variable is very limited and a value close to one means that the independent variables can provide all the information needed to predict the dependent variable. The greater the $\mathrm{R}$-square value or the coefficient of determination, the better the model. The value of determination is to test the diversity that is used to see how far the diversity can be explained by the independent variable on the dependent variable, namely to see how strongly the variables included in the model can explain the model (Iriawan and Astuti 2006). Table 3 shows that the green open space which has the highest Rsquare value is the WTP model per visit by the Beringin green open space visitor with a value of 0.968 which means the ability of the independent variable to explain the magnitude of variation in the dependent variable is $96.8 \%$, the remaining $3.2 \%$ is explained by other variables that are not included in the equation.

The $\mathrm{R}$ coefficient value explains the relationship between one variable and another. The results in Table 4 show that the R-value in the equation model is between 0.470-0.968. Riduwan (2009) states that an R-value that is close to one indicates a strong relationship between variables, whereas if it is positive then these variables have a unidirectional relationship, meaning that an increase in the value of one variable will coincide with an increase in other variables. The multiple linear regression method in this study will show the potential contribution of visitors to improve the quality of the environment by building or developing the green open space visited.

The regression model with p-value less than 0.05 means that this factor has a significant effect on the WTP value. In this study, Maharani's RTH has a p-value greater than 0.05 , which means that there is no factor in the equation that has a significant effect on giving the WTP value. In the Beringin RTH, the factor that influences the provision of WTP scores is the respondent's education, while the influencing factor in the provision of WTP in Cadika RTH is the age of the respondent.

Based on the results of the study, respondents gave a WTP value but there were also several reasons for respondents not to contribute. There were 6 respondents who were not willing to contribute. The following are the reasons why the visitor respondents are not willing to contribute are presented in Table 4. 
Tabel 3 Function of WTP visitors

\begin{tabular}{|c|c|c|}
\hline RTH & $\mathrm{R}$ & Regression Model \\
\hline Beringin & 0.984 & $\begin{array}{l}W T P=5848.084+326.203 J K-79.589 U M+1926.102 S P+ \\
45504.922 P D 3+337.896 P D 5+3577.798 P D 6+1075.900 P H 2- \\
2210.235 P H 3-2567.463 P H 4\end{array}$ \\
\hline Cadika & 0.700 & $\begin{array}{l}\text { WTP }=-22823.763+2144.640 \mathrm{JK}+1497.640 \mathrm{UM}-9509.837 \mathrm{SP}- \\
\text { 4993.050PD4 - 1926.574PD5 + 7108.244PH2 - 13375.443PH3 - } \\
\text { 1351.506PH4 }\end{array}$ \\
\hline Maharani & 0.470 & $\begin{array}{l}W T P=9437.992+4105.914 J K-251.049 U M+4285.511 S P- \\
2891.106 P D 5-2584.509 P D 6-1173.580 P H 2+7742.920 P H 3\end{array}$ \\
\hline $\begin{array}{l}\text { Notes : WT } \\
=\text { not scho } \\
\text { education } \\
\text { education } \\
-620000\end{array}$ & $W$ & $\begin{array}{l}\text { ness to pay, JK = Gender (Male/ female), UM = Age, SP = Marital Status (Single/ married), PD1 } \\
\text { Level of education elementary, PD3 = Level of education junior high school, PD4 = Level of } \\
\text { chool, PD5 = Level of education D1/D2/D3, PD6= Level of education S1, PD7 = Level of } \\
\text { ncome < Rp. 1,500,000; PH2 = income Rp. 1,500,000 - 3,100,000; PH3 = income Rp. 3,200,000 } \\
\text { ome Rp. 6,300,000 - 12,400,000; PH5 = income Rp. > 12,400,000. }\end{array}$ \\
\hline
\end{tabular}

Table 4. Reasons for respondents not to contribute

\begin{tabular}{|c|c|c|c|}
\hline Reason & Beringin & Cadika & Maharani \\
\hline The responsibility of government & 5 & 5 & 5 \\
\hline Economic factor & 3 & 2 & 3 \\
\hline The contribution is worried about being misused & 2 & 5 & 2 \\
\hline There is no need improvement & 2 & 2 & 2 \\
\hline Feeling no need for green space & 1 & 1 & 1 \\
\hline
\end{tabular}

Notes: 1 (very disagree), 2 (disagree), 3 (moderate), 4 (agree), 5 (very agree)

The reason respondents do not want to contribute with the highest scale (scale 5) to the three green open spaces is that respondents who are visitors think that this is the responsibility of the government so that visitors feel no need to set aside their income for the construction and development of green open space. In Cadika's RTH, the respondent's reason for not contributing is also because the respondent is worried that the contribution given will be misused by certain parties. The most inappropriate reason (scale 1) for the three green open spaces is the reason that visitors feel that they do not need the existence of green open spaces. So based on this statement it can be concluded that visitors still feel the need for the existence of green open space.

\section{b. Hedonic Price}

Hedonic price is an approach to get the price of property items that are influenced by attributes, including property characteristics, characteristics of the surrounding environment, and environmental quality. A person's decision in determining the purchase of a property is influenced by the quality of the environment, where the tendency of individuals to pay more to get a property with better environmental quality. The following is the average property price in the form of residences located around green open space as seen based on the radius of green open space (Table 6).

Based on table 6 , there are differences in property prices for each measurement radius for each green open space. In general, the closer the radius to the green open space, the more property prices at that location also increase. However, in some radius there is also a decrease in property prices, this is related to accessibility, such as the distance from access to four-wheeled vehicles as well as access from public transportation. The difference in property prices at each green space location is also influenced by the Sales Value of Taxable Object at that location (Medan Mayoral Regulation, 2020). The Beringin green open space which is a business and office area in the center of Medan has a higher price than the other two green open spaces. In Maharani's green open space, which has lower property prices, it is related to the location of green open space which is in an industrial area and far from the center of Medan City. This shows that the existence of green open space then affects property prices in the area.

In this study, an assessment of several factors suspected of influencing property prices were also 
carried out. The regression model shows the relationship between the independent variable and the dependent variable. The results of the regression model analysis are shown in Table 7.

Based on the results of the regression model analysis (Table 7) shows that in the three green open spaces, the presence of green open space increases property prices around the green open space area. The closer $1 \mathrm{~m}$ to the green space, the property prices will increase. Based on the distance variable to the isolated green open space, in the Beringin green open space which is a business and office area, there is an increase in the price of Rp. $54,346 / \mathrm{m}$, in Cadika RTH which is a residential area, there is an increase in the price of $\mathrm{Rp}$. $53,243 / \mathrm{m}$, and at Maharani RTH which is an industrial area, there is an increase in the price of Rp. 41,021/m.
Based on the regression model, RTH Cadika and RTH Maharani have a p-value greater than 0.05 , which means that there is no factor in the equation that has a significant effect on the value of WTP. In the Beringin green open space, the factors that influence the value of WTP are the status of residence, land area, and distance traveled to green open space. According to Rahmawati (2018) in her research, a city park that is close and can be seen directly from the place of residence means that it will provide more aesthetic value than a residence that cannot directly get a view of the city park landscape. This is the same as the results of research by Tyrvainen (1997) in Finland which shows that environmental variables, one of which is the distance between the apartment and the city park, has a significant positive impact on apartment prices

Table 6. Relationship between distance from green open space and property prices

\begin{tabular}{rrrr}
\hline Radius $(\mathrm{m})$ & Beringin $\left(\mathrm{Rp} / \mathrm{m}^{2}\right)$ & Cadika $\left(\mathrm{Rp} / \mathrm{m}^{2}\right)$ & Maharani $\left(\mathrm{Rp} / \mathrm{m}^{2}\right)$ \\
\hline 25 & $10,714,286$ & $5,286,990$ & $1,407,894$ \\
50 & $10,145,639$ & $3,961,353$ & $1,056,277$ \\
100 & $10,609,634$ & $3,387,670$ & 902,564 \\
500 & $9,562,122$ & $3,534,871$ & $1,235,691$ \\
\hline
\end{tabular}

Table 7. Function of hedonic price

\begin{tabular}{|c|c|c|}
\hline RTH & $\mathrm{R}$ & Regression Model \\
\hline Beringin & 0.977 & $\begin{aligned} & Y=-287590401.381+0.381 J N S+8546802.423 L T N-1616669.457 L B G \\
&+ 49660231.387 J R U-705813890.257 P K-21093717.338 J R K \\
&+45061304.039 J A E-158314502.470 J A T-487505358.110 J P S \\
&-54346.267 J T T\end{aligned}$ \\
\hline Cadika & 0.968 & $\begin{array}{l}Y=-19842026.662+0.609 J N S+636314.390 L T N-343236.552 L B G \\
-5443992.675 J R U-5684338.865 P K R+11050514.127 J R K \\
+1148484.036 J A E-77901.628 J A T-21213657.964 J P S \\
+53243.263 J T T\end{array}$ \\
\hline Maharani & 0.933 & $\begin{aligned} Y=-56311491.035 & +0.651 J N S+155490.600 L T N-225312.883 L B G \\
& +6679335.975 J R U-19620027.623 P K R-2435732.148 J R K \\
& +70414.830 J A E-21419886.395 J A T-8846863.077 J P S \\
& +41021.724 J T T\end{aligned}$ \\
\hline
\end{tabular}

Notes: $\mathrm{Y}=$ Property prices (building price) $\left(\mathrm{Rp} \mathrm{m}^{-2}\right), \mathrm{JNS}=$ respondent's building status (own $=1$, rent $\left.=0\right), \mathrm{LTN}=$ surface area $\left(\mathrm{m}^{2}\right), \mathrm{LBG}=$ building area $\left(\mathrm{m}^{2}\right), \mathrm{JRU}=$ numbers of room (unit), PKR $=$ yard (have $=1$, don't have $=0$ ), JRK = distance to office $(\mathrm{km}), \mathrm{JAE}=$ distance to four-wheeled vehicle access road $(\mathrm{km})$, JAT = distance to public transportation access road $(\mathrm{km})$, JPS $=$ distance to market/shopping center $(\mathrm{km}), \mathrm{JTT}=$ the distance to the nearest green open space $(\mathrm{m})$ 


\section{CONCLUSION}

The existence of green open space is perceived as important for the people. Overall, the existence of green open space provides the benefits of ameliorating the microclimate, but its capabilities differ based on the characteristics of green open space and the characteristics of the surroundings. The public perceives green open space as uncomfortable and in line with the THI value 26 with the uncomfortable category. Based on actual microclimate data, the air comfort conditions in green open space are better than outside green open space and make it important to pay attention to green open space management and development.

The value of the willingness of visitors to green open spaces to contribute (WTP) in improving environmental quality as a form of participation in increasing environmental comfort through the CVM and HPM methods. Through the CVM method, the total WTP value of visitors with a period per visit is estimated to be Rp. 29,268,000/year. This value describes the potential for visitor participation in funding the development and management of green open space in this case in the form of a green open space. Based on the hedonic price analysis, it shows that there is an influence of the existence of green open space on the price of residential property seen from its distance to green open space. The closer 1 meter to the green space will increase the price of different properties in each green open space.

\section{REFERENCES}

Badan Pusat Statistik Kota Medan. 2019. Kota Medan dalam angka tahun 2019. Bogor (ID): BPS

Effendy S, Bey A, Zain AFM, Santosa L. 2006. Peranan ruang terbuka hijau dalam mengendalikan suhu udara dan urban heat island wilayah Jabodetabek. $J$. Agromet Indonesia. 20(1):23-33.

Fauzi A. 2010. Ekonomi Sumber Daya Alam dan Lingkungan Teori dan Aplikasi. Jakarta: PT. Gramedia Pustaka Utama

Fauzi A. 2014. Valuasi Ekonomi dan Penilaian Kerusakan Sumber Daya Alam dan Lingkungan. Bogor (ID): IPB Press.

Garrod G, Willis KG. 1999. Economics Valuation of the Environment Method and Case Studies. Cheltenhem (UK). Edward Elgar Publishing Ltd.

Ghozali I. 2009. Ekonometrika: Teori, Konsep dan Aplikasi dengan SPSS 17. Semarang (ID): Badan Penerbit Diponegoro.
Iriawan N, Astuti SP. 2006. Mengolah Data Statistik Menggunakan Minitab 14. Yogyakarta (ID): Andi Yogyakarta.

Lakitan, B. 2002. Dasar-dasar klimatologi. Raja Grafindo Persada. Jakarta.

McGregor GR, Nieuwolt S. 1998. Tropical Climatologi, an Introduction to the Climates of the Low Latitude. New York (US): John Wiley and Sons.

Peraturan Pemerintah Republik Indonesia. 2007. Undang-Undang No 26 tahun 2007 tentang Tata Ruang. Jakarta: Sekretariat Negara.

Purwandani N, Faradisa H, Khairunnisa N. 2018. Analisis Hubungan Perubahan Suhu Udara Dengan Ketersediaan Ruang Terbuka Hijau Studi Kasus Di Kota Banjarmasin, Kalimantan Selatan. Seminar Nasional Geomatika 2018: Penggunaan Dan Pengembangan Produk Informasi Geospasial Mendukung Daya Saing Nasional.

Ramdhoni S, Rushayati SB, Prasetyo LB. 2016. Open green space development priority based on distribution of air temperature change in capital city of Indonesia. Procedia Environmental Science. (33):204-213.

Rahmawati SN. 2018. Nilai Ekonomi Taman Kota di Jakarta. Tesis. Bogor (ID): Institut Pertanian Bogor.

Riduwan. 2009. Pengantar Statistika Sosial. Bandung (ID): Alfabeta.

Sangkertadi. 2013. Pengaruh kecepatan angin terhadap tingkat kenyamanan termal di ruang luar iklim tropis lembap. Jurnal Lingkungan Binaan Indonesia. 2(1):26-34.

Setyowati DL. 2008. Iklim Mikro dan Kebutuhan Ruang Terbuka Hijau di Kota Semarang. Jurnal Manusia dan Lingkungan. 15(3):125-140.

Sugihartono, Fathiyah KN, Setiawati FA, Harahap F, Nurhayati SR. 2007. Psikologi Pendidikan. Yogyakarta. Penerbit UNY Press.

Suryandari EY, Alvia L. 2015. Faktor-Faktor Yang Memengaruhi Penyelenggaraan Hutan Kota: Studi Kasus Kota Medan, Deli Serdang Dan Palangka Raya. Bogor. Pusat Penelitian dan Pengembangan Perubahan Iklim dan Kebijakan

Tampubolon N. 2017. Valuasi kenyamanan lingkungan bagi masyarakat Kota Bandar Lampung. Tesis. Bogor (ID): Institut Pertanian Bogor.

Tyrväinen L. 1997. The amenity value of the urban forest: an application of the hedonic pricing method. Landscape and Urban planning 37 (3-4), 211-222. 